\title{
PENGARUH MODEL PEMBELAJARAN PROBLEM SOLVING BERBANTUAN PERMAINAN SNAKES AND LADDERS TERHADAP KOMPETENSI PENGETAHUAN MATEMATIKA SISWA
}

\author{
Ni Wayan Maretayani \\ Jurusan Pendidikan Guru Sekolah Dasar Universitas Pendidikan Ganesha \\ E-mail: maretayani@yahoo.com \\ I Wayan Wiarta \\ Jurusan Pendidikan Guru Sekolah Dasar Universitas Pendidikan Ganesha \\ E-mail: wayanwiarta.63 @gmail.com \\ I Ketut Ardana \\ Jurusan Pendidikan Guru Sekolah Dasar Universitas Pendidikan Ganesha \\ E-mail: ketut_ardana55@yahoo.co.id
}

\begin{abstract}
Abstrak
Penelitian ini bertujuan untuk mengetahui pengaruh model pembelajaran problem solving berbantuan permainan snakes and ladders terhadap kompetensi pengetahuan matematika siswa kelas III SD Gugus Dewi Sartika Kecamatan Denpasar Timur. Penelitian ini merupakan penelitian eksperimen dengan desain eksperimen semu (non-equivalent control group design). Populasi dalam penelitian ini adalah siswa kelas III SD Gugus Dewi Sartika Kecamatan Denpasar Timur tahun pelajaran 2016/2017. Penentuan sampel dilakukan dengan teknik random sampling. Sampel penelitian ini adalah siswa kelas IIIA SD Negeri 3 Kesiman sebagai kelompok eksperimen dan siswa kelas IIIA SD Negeri 10 Kesiman sebagai kelompok kontrol. Metode pengumpulan data dengan metode tes. Data yang dikumpulkan adalah kompetensi pengetahuan matematika yang dianalisis dengan uji t. Berdasarkan analisis data dengan uji $t$ diperoleh $t_{\text {hitung }}=3,61>t_{\text {tabel }}=2,00$ dengan $\mathrm{dk}=89$ dan taraf signifikansi $5 \%$ maka $\mathrm{H}_{0}$ ditolak dan $\mathrm{H}_{\mathrm{a}}$ diterima. Rata-rata kompetensi pengetahuan matematika siswa yang dibelajarkan melalui model pembelajaran problem solving berbantuan permainan snakes and ladders lebih dari ratarata siswa yang tidak dibelajarkan melalui model pembelajaran problem solving berbantuan permainan snakes and ladders $(\bar{X}=72,77>\bar{X}=62,67)$. Dengan demikian dapat disimpulkan bahwa penerapan model pembelajaran problem solving berbantuan permainan snakes and ladders berpengaruh terhadap kompetensi pengetahuan matematika siswa kelas III SD Gugus Dewi Sartika Kecamatan Denpasar Timur tahun pelajaran 2016/2017
\end{abstract}

Kata kunci: problem solving, snakes and ladders, kompetensi pengetahuan matematika

\begin{abstract}
This research aims to know the influence of problem solving learning model assisted by the game of snakes and ladders on the competence of mathematics knowledge of third grade students in SD Gugus Dewi Sartika East Denpasar District. This research was an experiment research with quasi experimental design (non-equivalent control group design). The population in this research was students of the third grade of SD Gugus Dewi Sartika East Denpasar District academic year 2016/2017. The sample of the research was carried out by random sampling. The sample of this research were students of the third grade A of SD Negeri 3 Kesiman as the experiment group and students of the third grade A of SD Negeri 10 Kesiman as the control group. The method of collecting data was the method of test. The data collected in the form of the competence of mathematics knowledge analyzed by $t$ test. Based on the $t$ test analysis obtained $t_{\text {count }}=3,61>t_{\text {table }}=2,00$ with $\mathrm{dk}=89$ and significant point $5 \%$, it mean $\mathrm{H}_{0}$ was denied and the $\mathrm{Ha}$ was received. The average competence of students mathematical knowledge through learning problem solving model assisted by the game of snakes and ladders more than the average of students who are not learned through the problem solving learning model assisted by the game of snakes and ladders $(\bar{X}=$ $72,77>\bar{X}=62,67)$. Based on the data above, it could be concluded that the application of problem solving learning model assisted by the game of snakes and ladders influences the competence of mathematics knowledge of third grade students of SD Gugus Dewi Sartika, East Denpasar District academic year 2016/2017.
\end{abstract}

Keywords : Problem Solving, Snakes And Ladders, The Competence Of Mathematics Knowledge

\section{Pendahuluan}

Pendidikan merupakan salah satu usaha manusia untuk mengembangkan potensi diri. Pendidikan yang baik adalah pendidikan yang tidak hanya mempersiapkan para siswanya untuk suatu profesi atau jabatan tertentu, tetapi untuk menyelesaikan masalah-masalah yang dihadapi dalam kehidupan sehari-hari. 
Adapun tujuan dari setiap satuan pendidikan mengacu ke arah pencapaian tujuan pendidikan nasional, sebagaimana telah diterapkan dalam Undang-undang RI No. 20 tahun 2003 tentang Sistem Pendidikan Nasional yaitu pendidikan nasional berfungsi mengembangkan kemampuan dan membentuk watak serta peradaban bangsa yang bermartabat dalam rangka mencerdaskan kehidupan bangsa, bertujuan mengembangkan potensi siswa agar menjadi manusia yang beriman dan bertaqwa kepada Tuhan Yang Maha Esa, berakhlak mulia, sehat, berilmu, cakap kreatif dan mandiri dan menjadi warga negara yang demokratis serta bertanggung jawab.

Pendidikan yang berlaku di Indonesia adalah pendidikan yang berakar pada nilai-nilai agama, kebudayaan nasional Indonesia dan tanggap terhadap tuntutan perubahan zaman. Perkembangan dan perubahan yang terjadi dalam kehidupan bermasyarakat, berbangsa dan bernegara sebagai dampak dari pengaruh perubahan global, perkembangan ilmu pengetahuan dan teknologi serta seni dan budaya menuntut perlunya perbaikan sistem perbaikan pendidikan nasional dengan berbagai upaya. Upaya tersebut antara lain perubahan dan perbaikan kurikulum, peningkatan daya dukung sarana dan prasarana, serta peningkatan mutu para pendidik dan peserta didik.

Dalam Undang-Undang RI tentang Sistem Pendidikan Nasional Nomor 20 tahun 2003, Bab I, Pasal 1 ayat 19 , kurikulum diartikan, "Seperangkat rencana dan pengaturan mengenai tujuan, isi, dan bahan pelajaran serta cara yang digunakan sebagai pedoman penyelenggaraan kegiatan pembelajaran untuk mencapai tujuan pendidikan tertentu." Dalam Permendikbud Nomor 57 tahun 2014 lampiran 1 menetapkan kurikulum pada Sekolah Dasar/Madrasah Ibtidaiyah yang telah dilaksanakan sejak tahun pelajaran 2013/2014 disebut Kurikulum 2013 Sekolah Dasar/Madrasah Ibtidaiyah. Kurikulum 2013 adalah salah satu upaya pemerintah untuk memperbaiki pendidikan agar dapat mencetak manusia yang berkualitas dan mampu proaktif menjawab tantangan zaman yang selalu berubah. Kurikulum 2013 memiliki sejumlah perubahan dibandingkan kurikulum sebelumnya. Karena perubahan ini, diperlukan sejumlah persiapan yang harus dilakukan oleh tiap pengelola satuan pendidikan (Prastowo, 2015).

Menurut Undang-Undang Sistem Pendidikan Nasional No 20 tahun 2003, Pasal 1 Ayat 20, "Pembelajaran adalah proses interaksi peserta didik dengan pendidik dan sumber belajar pada suatu lingkungan belajar." Salah satu faktor yang yang sangat berperan memengaruhi kompetensi pengetahuan siswa adalah guru. "Guru dalam proses pembelajaran memegang peranan yang sangat penting" (Susanto, 2015:13). Dalam kurikulum 2013 siswa dituntut melalui beberapa proses secara aktif mencari, mengolah, mengkonstruksi, dan menerapkan pengetahuan. Maka sangat diperlukan upaya inovasi guru dalam mensiasati pembelajaran di kelas.

Berdasarkan observasi pada tanggal 28 Desember 2016 dan 19 Januari 2017 dengan ketua gugus, kepala sekolah serta guru kelas III yang terdiri dari 6 SD Negeri dengan 12 kelas di SD Gugus Dewi Sartika Kecamatan Denpasar Timur dalam proses pembelajaran terutama menyangkut bidang matematika masih banyak kelemahan dilihat dari hasil belajar matematika siswa terutama kompetensi pengetahuan. Hal ini dapat dilihat dari predikat kompetensi pengetahuan matematika yang diperoleh siswa di SD Gugus Dewi Sartika yaitu siswa yang mendapatkan predikat A sebanyak 23,26\%, predikat B sebanyak 44,96\%, predikat C sebanyak $23,51 \%$ dan siswa yang mendapatkan predikat D sebanyak 8,27\% dari 387 siswa.

Kompetensi adalah kemampuan seseorang untuk bersikap, menggunakan pengetahuan dan keterampilan untuk melaksanakan suatu tugas di sekolah, masyarakat, dan lingkungan (Suarjana, 2015). Kompetensi dasar adalah kemampuan minimal yang harus dicapai peserta didik dalam konsep atau materi pelajaran yang diberikan dalam kelas pada jenjang pendidikan tertentu (Prastowo, 2015). Matematika merupakan suatu mata pelajaran yang selama ini dianggap sebagai beban bagi siswa karena menyelesaikan permasalahan dalam matematika tidak mudah. Siswa cenderung takut, bahkan tidak menyukai pelajaran matematika. Siswa malas belajar matematika sehingga pada akhirnya tidak memiliki pengetahuan yang memadai tentang matematika. Hanya sebagian kecil siswa yang menyukai matematika. Padahal, matematika merupakan salah satu mata pelajaran penting yang menentukan lulus tidaknya seseorang dalam menempuh jenjang pendidikan sekolahnya. Selain itu, unsur-unsur matematika menyertai kita dalam kehidupan seharihari.

Kompetensi pengetahuan matematika siswa dipengaruhi oleh beberapa faktor seperti dari matematika itu sendiri. Dalam hal ini, matematika menuntut analisa pemecahan masalah dan perhitungan sedangkan kebanyakan siswa cenderung memilih hafalan. Matematika dianggap sulit dan tidak menyenangkan oleh siswa sehingga tidak memperhatikan ketika guru menjelaskan, bermain-main, dan berada di dunianya sendiri. Padahal guru sangat berperan penting dalam proses pembelajaran matematika.

Melihat persoalan tersebut, seorang guru harus kreatif dalam melakukan proses pembelajaran agar pembelajaran matematika menyenangkan dan disukai oleh siswa. Guru dapat memilih model pembelajaran inovatif untuk pembelajaran matematika. Pembelajaran inovatif merupakan pembelajaran yang memberikan kesempatan kepada peserta didik untuk mengemukakan ide-ide baru atau gagasan -gagasan untuk perbaikan atau pengembangan dalam kegiatan pembelajaran (Ngalimun, 2016). Salah satunya dengan model pembelajaran problem solving atau pemecahan masalah. 
Problem solving adalah model mengajar yang digunakan oleh guru dalam proses pembelajaran yang meliputi kemampuan untuk mencari informasi, menganalisis situasi, dan mengidentifikasi masalah dengan tujuan untuk menghasilkan alternatif sehingga dapat mengambil suatu tindakan untuk mencapai sasaran (Shoimin, 2014). Dalam hal ini masalah didefinisikan sebagai suatu persoalan yang tidak rutin dengan mencari atau menemukan cara penyelesaian (menemukan pola, aturan). Model pembelajaran problem solving dilakukan dengan memberikan suatu permasalahan yang kemudian dicari penyelesaiannya dengan dimulai dari mencari data sampai pada kesimpulan (Ambarjaya, 2012).

Sintaks dari model pembelajaran problem solving menurut Russel (2016) yang didukung oleh pendapat Huda (2013) sebagai berikut. Langkah pertama adalah clues yaitu pemahaman masalah, langkah kedua adalah game plan yaitu perencanaan penyelesaian masalah, langkah ketiga adalah solve yaitu menggunakan strategi dalam penyelesaian masalah, dan langkah keempat adalah reflect yaitu melihat kembali solusi yang digunakan.

Model pembelajaran problem solving dapat dipadukan dengan permainan. Dalam membuat permainan, guru dapat menyesuaikan jenis permainan yang digunakan dengan materi yang berkaitan agar suasana belajar menjadi lebih menyenangkan. Permainan adalah suatu aktivitas yang menyenangkan bagi anak yang mampu mengembangkan seluruh aspek perkembangan anak.

Bermain memberikan manfaat untuk anak, yaitu mendapatkan kegembiraan dan hiburan, mengembangkan kecerdasan intelektual, mengembangkan kemampuan motorik halus dan motorik kasar anak, meningkatkan kemampuan anak untuk berkonsentrasi, meningkatkan kemampuan anak untuk memecahkan masalah, mendorong spontanitas anak, mengembangkan kemampuan sosial anak, sebagai media untuk mengungkapkan pikiran, dan untuk kesehatan (Achroni, 2012).

Dalam penelitian ini akan menggunakan permainan snakes and ladders atau ular tangga. Permainan snakes and ladders sudah dikenal oleh anak-anak bahkan sampai orang tua karena permainan ini memiliki peraturan yang sederhana. Dengan bantuan permainan snakes and ladders dalam model pembelajaran problem solving pada proses pembelajaran matematika diharapkan dapat memotivasi siswa dalam belajar matematika, meningkatkan rangsangan belajar untuk memecahkan masalah matematika, dan meningkatkan kerjasama siswa untuk memecahkan masalah-masalah matematika.

Berdasarkan pemaparan permasalahan tersebut, maka dilakukan sebuah penelitian dengan judul "Pengaruh Model Pembelajaran Problem Solving Berbantuan Permainan Snakes and Ladders terhadap Kompetensi Pengetahuan Matematika Siswa Kelas III SD Gugus Dewi Sartika Kecamatan Denpasar Timur". Adapun tujuan dilakukan penelitian ini adalah untuk mendeskripsikan kompetensi pengetahuan matematika kelompok siswa yang dibelajarkan dengan model pembelajaran problem solving berbantuan permainan snakes and ladders dan kompetensi pengetahuan matematika kelompok siswa yang tidak dibelajarkan dengan model pembelajaran problem solving berbantuan permainan snakes and ladders, dan untuk mengetahui pengaruh model pembelajaran problem solving berbantuan permainan snakes and ladders terhadap kompetensi pengetahuan matematika siswa kelas III SD Gugus Dewi Sartika Kecamatan Denpasar Timur tahun pelajaran $2016 / 2017$.

\section{Metode Penelitian}

Jenis penelitian yang digunakan adalah penelitian kuantitatif yaitu penelitian eksperimen dengan desain eksperimen semu (quasy experimental design) yang digunakan dalam penelitian ini yaitu non-equivalent control group design (Sugiyono, 2014). Pada bentuk desain non-equivalent control group design, terdapat dua kelompok sampel yang terdiri dari kelompok eksperimen dan kelompok kontrol sebagai subjek penelitian yang akan dibandingkan.

Berdasarkan desain eksperimen semu dengan bentuk non-equivalent control group design, maka hanya diperhitungkan skor post test saja tanpa memperhitungkan skor pre test karena tujuan dilakukan penelitian ini hanya untuk mengetahui perbedaan bukan peningkatan kompetensi pengetahuan matematika pada kelompok eksperimen yang diberikan perlakuan model pembelajaran problem solving berbantuan permainan snakes and ladders dan kelompok kontrol yang tidak diberikan perlakuan model pembelajaran problem solving berbantuan permainan snakes and ladders. Pre test diberikan untuk kelompok kontrol dan kelompok eksperimen. Pre test hanya dilakukan sebagai penyetaraan kelompok (Dantes, 2012).

Populasi dari penelitian ini adalah siswa kelas III SD Gugus Dewi Sartika Kecamatan Denpasar Timur tahun pelajaran 2016/2017, yang terdiri dari 387 siswa dalam 6 Sekolah Dasar yaitu SD Negeri 3 Kesiman, SD Negeri 7 Kesiman, SD Negeri 10 Kesiman, SD Negeri 12 Kesiman, SD Negeri 16 Kesiman, dan SD Negeri 17 Kesiman. Berdasarkan hasil wawancara yang diperoleh dari ketua gugus, kepala sekolah serta guru wali kelas III di masing-masing SD Gugus Dewi Sartika Kecamatan Denpasar Timur bahwa kelas III dari 6 sekolah dengan 12 kelas yang ada di Gugus Dewi Sartika tidak terdapat kelas unggulan maupun non unggulan, karena siswa dalam kelas disetiap sekolah di gugus ini disebar secara merata antara siswa yang memiliki kemampuan tinggi, sedang, dan rendah. 
Teknik pengambilan sampel pada penelitian ini adalah random sampling sehingga setiap kelas mendapatkan peluang yang sama untuk menjadi sampel penelitian. Sebelum menentukan sampel yang dijadikan sebagai kelompok eksperimen dan kelompok kontrol, sampel tersebut diuji kesetaraannya. Uji kesetaraan tersebut berdasarkan data hasil pre test dengan menggunakan rumus uji t dengan polled varian (Sugiyono, 2014). Dari enam sekolah negeri yang ada di Gugus Dewi Sartika Kecamatan Denpasar Timur dilakukan dua kali pengundian. Pengundian tahap pertama untuk memilih dua kelas yang dijadikan sampel penelitian. Kedua kelas yang terpilih menjadi sampel kemudian diberikan pre test. Untuk penyetaraan sampel penelitian, nilai atau skor dari hasil pre test dianalisis menggunakan uji t. Sebelum melaksanakan uji t, dilakukan uji prasyarat yaitu normalitas dan homogenitas. Setelah dinyatakan setara, sampel penelitian diundi kembali untuk menentukan kelompok eksperimen dan kelompok kontrol. Setelah dilakukan pengundian, kelas IIIA SD Negeri 3 Kesiman berjumlah 52 siswa muncul pertama sebagai kelompok eksperimen dibelajarkan dengan model pembelajaran problem solving berbantuan permainan snakes and ladders dan kelas IIIA SD Negeri 10 Kesiman yang berjumlah 39 siswa muncul kedua sebagai kelompok kontrol tidak dibelajarkan dengan model pembelajaran problem solving berbantuan permainan snakes and ladders.

Metode yang digunakan dalam penelitian ini adalah teknik tes. Data tes yang dikumpulkan dalam penelitian ini adalah data tes kompetensi pengetahuan matematika. Jenis tes yang digunakan dalam penelitian ini adalah tes objektif tipe Pilihan Ganda Biasa (PGB) dengan empat opsi (pilihan jawaban) dan satu opsi diantara empat opsi tersebut merupakan jawaban yang tepat. Instrumen atau tes yang digunakan dalam penelitian ini diuji coba melalui uji validitas, daya beda, indeks kesukaran, dan reliabilitas. Hasil tes uji coba tersebut selanjutnya diberikan kepada kelompok eksperimen dan kelompok kontrol sebagai post test.

Analisis data yang digunakan dalam penelitian ini adalah statistik dekskriptif dan statistik Inferensial (Koyan, 2012). Statistik dekskriptif adalah menentukan nilai rata-rata (mean), standar deviasi dan varians data kompetensi pengetahuan matematika kelompok eksperimen dan kelompok kontrol. Statistik inferensial yang dilakukan adalah uji hipotesis menggunakan uji t, tetapi sebelumnya dilaksanakan uji prasyarat berupa uji normalitas dan uji homogenitas varians. Dalam penelitian ini data disajikan dalam bentuk tabel nominal.

\section{Hasil dan Pembahasan Hasil Penelitian}

Adapun hasil analisis deskripsi data kompetensi pengetahuan matematika siswa yang diperoleh kelompok eksperimen dan kelompok kontrol disajikan pada tabel 1.

Tabel 1. Deskripsi Data Kompetensi Pengetahuan Matematika Kelompok Eksperimen dan Kelompok Kontrol

\begin{tabular}{lcc}
\multicolumn{1}{c}{ Hasil Analisis } & Kelompok Eksperimen & Kelompok Kontrol \\
\hline Rata-rata (Mean) & 72,77 & 62,67 \\
\hline Standar Deviasi & 12,50 & 14,19 \\
\hline Varians & 156,26 & 201,54 \\
\hline Nilai Maksimum & 96 & 92 \\
\hline Nilai Minimum & 44 & 40 \\
\hline
\end{tabular}

Berdasarkan tabel 1, nilai mean atau rata-rata kompetensi pengetahuan matematika siswa yang mengikuti pembelajaran dengan model pembelajaran problem solving berbantuan permainan snakes and ladders, yaitu $\bar{X}=72,77$ dengan varians 156,26 dan standar deviasi (s = 12,50 ). Rata-rata persentase kompetensi pengetahuan matematika yang diperoleh adalah $72,77 \%$ dikategorikan menggunakan kriteria PAP skala lima dan berada pada kategori sedang. Nilai mean atau rata-rata kompetensi pengetahuan matematika siswa yang tidak dibelajarkan dengan model pembelajaran problem solving berbantuan permainan snakes and ladders, yaitu $\bar{X}=62,67$ dengan varians 201,54 dan standar deviasi (s = 14,19). Rata-rata persentase kompetensi pengetahuan matematika yang diperoleh adalah 62,67\% dikategorikan menggunakan kriteria PAP skala lima dan berada pada kategori rendah. Perhitungan analisis data hasil penelitian yang diperoleh menunjukkan bahwa kompetensi pengetahuan matematika kelompok eksperimen memiliki nilai rata-rata atau mean lebih dari kelompok kontrol, yaitu $\bar{X}=72,77>\bar{X}=62,67$.

Pengujian asumsi yang dilakukan pada penelitian ini meliputi uji normalitas sebaran data dan uji homogenitas varians hasil post test kelompok eksperimen dan kelompok kontrol. Berdasarkan hasil perhitungan uji normalitas dengan Chi Square data post test kelompok eksperimen diperoleh $\mathrm{X}^{2}$ hit $=4,74$ sedangkan taraf signifikansi 5\% dan derajat kebebasan $(\mathrm{dk})=5$ diperoleh $\mathrm{X}_{\text {tabel }}^{2}=11,07$. Karena $\mathrm{X}^{2}$ hitung $=4,74$ $<\mathrm{X}_{\text {tabel }}^{2}=11,07$, ini berarti sebaran data post test kelompok eksperimen berdistribusi normal. 
Pada kelompok kontrol diperoleh $\mathrm{X}^{2}$ hitung $=2,32$ sedangkan taraf signifikansi $5 \%$ dan derajat kebebasan $(\mathrm{dk})=5$ diperoleh $\mathrm{X}_{\text {tabel }}^{2}=11,07$. Karena $\mathrm{X}_{\text {hitung }}^{2}=2,32<\mathrm{X}_{\text {tabel }}=11,07$, ini berarti sebaran data post test kelompok kontrol berdistribusi normal.

Setelah melakukan uji prasyarat uji normalitas, selanjutnya dilakukan uji prasyarat uji homogenitas varians data kompetensi pengetahuan matematika dianalisis menggunakan uji $\mathrm{F}$ dengan kriteria kedua kelompok memiliki varians homogen jika $\mathrm{F}_{\text {hitung }}<\mathrm{F}_{\text {tabel }}$ dengan dk pembilang $=\mathrm{n}-1$ dan dk penyebut $=\mathrm{n}-1$. Berdasarkan hasil analisis dengan uji $\mathrm{F}$ diperoleh $\mathrm{F}_{\text {hitung }}$ data kompetensi pengetahuan matematika siswa kelompok eksperimen dan kelompok kontrol adalah 1,29 sedangkan $\mathrm{F}_{\text {tabel }}$ yang diperoleh dari tabel nilai-nilai distributif $\mathrm{F}$ dengan derajat kebebasan pembilang $(\mathrm{dk}$ pembilang $=38)$ dan derajat kebebasan penyebut $(\mathrm{dk}$ penyebut $=51$ ) pada taraf signifikansi $5 \%$ adalah 1,63. Karena $F_{\text {hitung }}=1,29<F_{\text {tabel }}=1,63$, ini berarti varians data kompetensi pengetahuan matematika kelompok eksperimen dan kelompok kontrol adalah homogen.

Berdasarkan tabel 1, nilai mean atau rata-rata kompetensi pengetahuan matematika siswa yang mengikuti pembelajaran dengan model pembelajaran problem solving berbantuan permainan snakes and ladders, yaitu $\bar{X}=72,77$ dengan varians 156,26 dan standar deviasi (s = 12,50). Rata-rata persentase kompetensi pengetahuan matematika yang diperoleh adalah 72,77\% dikategorikan menggunakan kriteria PAP skala lima dan berada pada kategori sedang. Nilai mean atau rata-rata kompetensi pengetahuan matematika siswa yang tidak dibelajarkan dengan model pembelajaran problem solving berbantuan permainan snakes and ladders, yaitu $\bar{X}=62,67$ dengan varians 201,54 dan standar deviasi $(\mathrm{s}=14,19)$. Rata-rata persentase kompetensi pengetahuan matematika yang diperoleh adalah 62,67\% dikategorikan menggunakan kriteria PAP skala lima dan berada pada kategori rendah. Perhitungan analisis data hasil penelitian yang diperoleh menunjukkan bahwa kompetensi pengetahuan matematika kelompok eksperimen memiliki nilai rata-rata atau mean lebih dari kelompok kontrol, yaitu $\bar{X}=72,77>\bar{X}=62,67$.

Pengujian asumsi yang dilakukan pada penelitian ini meliputi uji normalitas sebaran data dan uji homogenitas varians hasil post test kelompok eksperimen dan kelompok kontrol. Berdasarkan hasil perhitungan uji normalitas dengan Chi Square data post test kelompok eksperimen diperoleh $\mathrm{X}^{2}$ hit $=4,74$ sedangkan taraf signifikansi $5 \%$ dan derajat kebebasan $(\mathrm{dk})=5$ diperoleh $\mathrm{X}_{\text {tabel }}^{2}=11,07$. Karena $\mathrm{X}^{2}{ }_{\text {hitung }}=4,74$ $<\mathrm{X}_{\text {tabel }}^{2}=11,07$, ini berarti sebaran data post test kelompok eksperimen berdistribusi normal

Pada kelompok kontrol diperoleh $\mathrm{X}^{2}$ hitung $=2,32$ sedangkan taraf signifikansi 5\% dan derajat kebebasan $(\mathrm{dk})=5$ diperoleh $\mathrm{X}_{\text {tabel }}^{2}=11,07$. Karena $\mathrm{X}^{2}$ hitung $=2,32<\mathrm{X}_{\text {tabel }}^{2}=11,07$, ini berarti sebaran data post test kelompok kontrol berdistribusi normal.

Setelah melakukan uji prasyarat uji normalitas, selanjutnya dilakukan uji prasyarat uji homogenitas varians data kompetensi pengetahuan matematika dianalisis menggunakan uji $\mathrm{F}$ dengan kriteria kedua kelompok memiliki varians homogen jika $\mathrm{F}_{\text {hitung }}<\mathrm{F}_{\text {tabel }}$ dengan $\mathrm{dk}$ pembilang $=\mathrm{n}-1$ dan dk penyebut $=\mathrm{n}-1$. Berdasarkan hasil analisis dengan uji $\mathrm{F}$ diperoleh $\mathrm{F}_{\text {hitung }}$ data kompetensi pengetahuan matematika siswa kelompok eksperimen dan kelompok kontrol adalah 1,29 sedangkan $\mathrm{F}_{\text {tabel }}$ yang diperoleh dari tabel nilai-nilai distributif $\mathrm{F}$ dengan derajat kebebasan pembilang $(\mathrm{dk}$ pembilang $=38)$ dan derajat kebebasan penyebut $(\mathrm{dk}$ penyebut $=51$ ) pada taraf signifikansi $5 \%$ adalah 1,63 . Karena $F_{\text {hitung }}=1,29<F_{\text {tabel }}=1,63$, ini berarti varians data kompetensi pengetahuan matematika kelompok eksperimen dan kelompok kontrol adalah homogen.

Uji hipotesis dilakukan untuk menguji hipotesis penelitian yang diajukan. Adapun hipotesis penelitian yang diuji adalah sebagai berikut.

H0 : tidak terdapat perbedaan yang signifikan kompetensi pengetahuan matematika antara kelompok siswa yang dibelajarkan melalui model pembelajaran problem solving berbantuan permainan snakes and ladders dan kelompok siswa yang tidak dibelajarkan melalui model pembelajaran problem solving berbantuan permainan snakes and ladders pada kelas III SD Gugus Dewi Sartika Denpasar Timur.

Adapun kriteria pengujiannya adalah apabila $t_{\text {hitung }} \leq t_{\text {tabel }}$, maka $\mathrm{H}_{0}$ diterima dan $\mathrm{H}_{\mathrm{a}}$ ditolak. Sebaliknya apabila $t_{\text {hitung }}>t_{\text {tabel }}$, maka $\mathrm{H}_{0}$ ditolak dan $\mathrm{H}_{\mathrm{a}}$ diterima dengan $\mathrm{dk}=\mathrm{n} 1+\mathrm{n} 2-2$ dan taraf signifikansi $5 \%$.

Berdasarkan hasil analisis uji t dari nilai post test kompetensi pengetahuan matematika siswa diperoleh hasil pada tabel 2 sebagai berikut.

Tabel 2. Hasil Analisi Uji-t Data Kompetensi Pengetahuan Matematika

\begin{tabular}{clccccccc}
\hline No & Sampel & $\mathrm{N}$ & $\mathrm{Dk}$ & $\bar{X}$ & $\mathrm{~S}^{2}$ & $\mathrm{t}_{\text {hitung }}$ & $\mathrm{t}_{\text {tabel }}$ & Status \\
\cline { 1 - 5 } 1 & $\begin{array}{l}\text { Kelompok } \\
\text { eksperimen }\end{array}$ & 52 & 51 & 72,77 & 156,26 & 3,61 & 2,00 & $\mathrm{H}_{0}$ ditolak \\
\cline { 1 - 5 } 2 & $\begin{array}{l}\text { Kelompok } \\
\text { kontrol }\end{array}$ & 39 & 38 & 62,67 & 201,54 & & & \\
\hline
\end{tabular}


Berdasarkan hasil analisis data diperoleh $t_{\text {hitung }}=3,61$ dengan taraf signifikansi $5 \%$ dan $\mathrm{dk}=52+39-$ $2=89$ diperoleh batas penolakan hipotesis nol, $\mathrm{t}_{\text {tabel }}=2,00$. Hal ini berarti $\mathrm{t}_{\text {hitung }}=3,61>\mathrm{t}_{\text {tabel }}=2,00 \mathrm{maka}_{0}$ ditolak dan $\mathrm{H}_{\mathrm{a}}$ diterima. Maka dapat diinterpretasikan bahwa terdapat perbedaan yang signifikan kompetensi pengetahuan matematika kelompok siswa yang dibelajarkan dengan model pembelajaran problem solving berbantuan permainan snakes and ladders dan kelompok siswa yang tidak dibelajarkan dengan model pembelajaran problem solving berbantuan permainan snakes and ladders pada siswa kelas III Gugus Dewi Sartika Denpasar Timur.

\section{Pembahasan}

Dengan diterapkannya model pembelajaran problem solving berbantuan permainan snakes and ladders pada kelompok eksperimen dan pembelajaran tidak dengan model pembelajaran problem solving berbantuan permainan snakes and ladders pada kelompok kontrol menunjukkan adanya perbedaan kompetensi pengetahuan matematika siswa kelas III SD Gugus Dewi Sartika Kecamatan Denpasar Timur. Hal ini dibuktikan dengan hasil analisis uji $\mathrm{t}$ diperoleh $\mathrm{t}_{\text {hitung }}=3,61>\mathrm{t}_{\text {tabel }}=2,00$ pada taraf signifikansi $5 \%$ dan $\mathrm{dk}=$ 89. Perbedaan ini disebabkan karena perbedaan perlakuan pada pembelajaran kelompok eksperimen dan kelompok kontrol.

Perbedaan perlakuan antara kelompok siswa yang dibelajarkan melalui model pembelajaran problem solving berbantuan permainan snakes and ladders dan kelompok siswa yang tidak dibelajarkan dengan model pembelajaran problem solving berbantuan permainan snakes and ladders memberikan dampak yang berbeda terhadap kompetensi pengetahuan matematika siswa. Kompetensi pengetahuan matematika siswa dapat dilihat dari mean atau rata-rata hasil post test. Berdasarkan hasil post test diperoleh mean kelompok eksperimen lebih dari mean kelompok kontrol yaitu $\bar{X}=72,77>\bar{X}=62,67$.

Kelompok eksperimen dibelajarkan dengan model pembelajaran problem solving berbantuan permainan snakes and ladders. Problem solving merupakan suatu keterampilan yang meliputi kemampuan untuk mencari informasi, menganalisis situasi, dan mengidentifikasi masalah dengan tujuan untuk menghasilkan alternatif sehingga dapat mengambil suatu tindakan untuk mencapai sasaran. Model pembelajaran problem solving yang dipadukan dengan permainan snakes and ladders lebih menyenangkan bagi siswa karena permainan snakes and ladder atau ular tangga sudah dikenal oleh siswa dan memiliki peraturan yang sederhana. Dalam permainan snakes and ladders terdapat petak-petak bernomor. Beberapa nomernya memiliki masalah yang harus diselesaikan oleh siswa. Model pembelajaran problem solving berbantuan permainan snakes and ladders pada pembelajaran matematika dapat memotivasi siswa dalam belajar matematika, meningkatkan rangsangan belajar untuk memecahkan masalah matematika, dan meningkatkan kerjasama siswa untuk memecahkan masalah-masalah matematika.

Sedangkan pada kelompok kontrol diterapkan pembelajaran yang biasa dilaksanakan sehari-hari sesuai kurikulum 2013 dengan pendekatan saintifik yaitu proses ilmiah yang terdiri dari lima komponen pengalaman belajar, yaitu menanya, mengamati, mengumpulkan informasi/mencoba, mengasosiasikan/menalar, dan mengomunikasikan, sehingga siswa terlibat secara aktif dalam mengonstruksikan pengetahuan

Hasil penelitian ini memperkuat penelitian yang dilakukan oleh Astra (2013) menunjukkan kemampuan pemecahan masalah siswa kelas IV Gugus III Kecamatan Sukasada yang mengikuti pembelajaran dengan model problem solving berbantuan media video pembelajaran matematika lebih baik dibandingkan dengan kemampuan pemecahan masalah siswa yang mengikuti pembelajaran konvensional. Hal serupa dinyatakan pula dalam penelitian Hendrawan (2013) menunjukkan hasil belajar matematika siswa kelas V SD Gugus VII Kecamatan Tejakula yang mengikuti pembelajaran dengan metode problem solving lebih baik dibandingkan dengan hasil belajar siswa yang mengikuti pembelajaran konvensional. Nopiani (2013) menunjukkan hasil belajar matematika siswa kelas IV SD Gugus VIII Sukawati yang mengikuti pembelajaran dengan model pembelajaran TGT berbantuan media permainan ular tangga lebih baik dibandingkan dengan hasil belajar siswa yang mengikuti pembelajaran konvensional.

Berdasarkan pemaparan tersebut, maka model pembelajaran problem solving berbantuan permainan snakes and ladders berpengaruh terhadap kompetensi pengetahuan matematika siswa.

\section{Simpulan dan Saran}

Berdasarkan hasil analisis uji t diperoleh thitung sebesar 3,61 dan ttabel dengan $\mathrm{dk}=89$ pada taraf signifikansi $5 \%$ adalah 2,00 maka $t_{\text {hitung }}>\mathrm{t}_{\text {tabel }}(3,61>2,00)$ sehingga $\mathrm{H}_{0}$ yang menyatakan tidak terdapat perbedaan yang signifikan kompetensi pengetahuan matematika antara kelompok siswa yang dibelajarkan melalui model pembelajaran problem solving berbantuan permainan snakes and ladders dan kelompok siswa yang tidak dibelajarkan melalui model pembelajaran problem solving berbantuan permainan snakes and ladders pada kelas III SD Gugus Dewi Sartika Kecamatan Denpasar Timur ditolak, dan $\mathrm{H}_{\mathrm{a}}$ diterima. Berdasarkan hasil penelitian terdapat perbedaan nilai rata-rata atau mean kompetensi pengetahuan matematika 
kelompok eksperimen yang dibelajarkan melalui model pembelajaran problem solving berbantuan permainan snakes and ladders dan kelompok kontrol yang yang tidak dibelajarkan melalui model pembelajaran problem solving berbantuan permainan snakes and ladders. Rata-rata kompetensi pengetahuan matematika kelompok eksperimen lebih dari rerata kelompok kontrol $(\bar{X}=72,77>\bar{X}=62,67)$. Hal ini membuktikan bahwa terdapat pengaruh model pembelajaran problem solving berbantuan permainan snakes and ladders terhadap kompetensi pengetahuan matematika siswa kelas III SD Gugus Dewi Sartika Kecamatan Denpasar Timur tahun pelajaran 2016/2017.

Berdasarkan hasil penelitian ini, dapat disarankan kepada (1) guru, diharapkan guru dapat menambah wawasan dan pengetahuan tentang mengembangkan inovasi dalam merancang pembelajaran yang bertujuan untuk memperoleh kompetensi pengetahuan yang optimal, guru dapat menerapkan model pembelajaran problem solving yang dapat dipadukan dengan permainan snakes and ladder sehingga dapat menarik minat dan menimbulkan rasa senang siswa dalam pembelajaran sehingga dapat memberikan kontribusi yang baik terhadap kompetensi pengetahuan siswa, (2) siswa, berdasarkan temuan penelitian, disarankan kepada siswa agar memanfaatkan kesempatan yang difasilitasi guru dengan berpartisipasi aktif dalam kegiatan pembelajaran dengan diterapkannya model pembelajaran problem solving berbantuan permainan snakes and ladders pada pembelajaran matematika, siswa lebih aktif dan dapat mengembangkan kreativitasnya dalam mengikuti pembelajaran serta membantu membangun pengetahuannya sendiri melalui pengalaman belajar untuk meningkatkan kompetensi pengetahuan siswa, dengan demikian siswa mampu mengaplikasikan apa yang telah diperoleh dalam pembelajaran yang nantinya akan diterapkan dalam kehidupan sehari-hari, (3) sekolah, hasil penelitian ini dapat dijadikan pedoman bagi sekolah untuk menciptakan kondisi yang mampu memotivasi dan meningkatkan kualitas guru-guru dalam merancang pembelajaran yang inovatif dalam membelajarkan siswa sesuai dengan yang diharapkan dalam kurikulum 2013, sehingga dapat meningkatkan mutu dan kualitas sekolah menjadi lebih baik,dan (4) peneliti lain, peneliti lain dapat melakukan penelitian lebih lanjut mengenai model pembelajaran problem solving berbantuan permainan snakes and ladders pada tema dan pembelajaran yang lain dan dapat mengembangkannya lagi untuk memperoleh hasil yang lebih baik.

\section{Daftar Pustaka}

Achroni, Keen. 2012. Mengoptimalkan Tumbuh Kembang Anak melalui Permainan Tradisional Panduan untuk Orangtua dan Guru. Yogjakarta: Javalitera.

Agung, A.A Gede. 2014. Metodologi Penelitian Pendidikan. Singaraja: Aditya Media Publishing.

Ambarjaya, Beni. 2012. Psikologi Pendidikan \& Pengajaran Teori \& Praktik. Yogyakarta: CAPS.

Astra, Gst.Ngr.Wira. 2013. "Pengaruh Model Pembelajaran Problem Solving Berbantuan Media Video Pembelajaran Matematika terhadap Kemampuan Pemecahan Masalah Siswa IV Gugus IV Kecamatan Sukasada”. Jurnal.Universitas Pendidikan Ganesha

Dantes, Nyoman. 2012. Metode Penelitian. Yogyakarta: Andi.

Hanif, Mochammad. 2016. 100 Game Seru. Jakarta: Saufan

Hendrawan, Kd Arya Dwi. 2013. "Pengaruh Metode Problem Solving terhadap Hasil Belajar Matematika Siswa Kelas V SD Ggus VII Kecamatan Tejakula”.Jurnal.Universitas Pendidikan Ganesha

Huda, Miftahul. 2013. Model-model Pengajaran dan Pembelajaran: Isu-Isu Metodis dan Paradigmatis. Yogyakarta: Pustaka Pelajar.

Koyan, I Wayan. 2012. Statistik Pendidikan Teknik Analisis Data Kuantitatif. Singaraja: Universitas Pendidikan Ganesha Press.

Muliawan, Jasa Ungguh. 2016. 45 Model Pembelajaran Spektakuler. Yogyakarta: Ar-Ruzz Media.

Mulyani, Novi. 2016. Super Asyik Permainan Tradisional Anak Indonesia. Yogyakarta: Diva Press.

Ngalimun. 2016. Strategi dan Model Pembelajaran.Yogyakarta: Aswaja Pressindo.

Nopiani, Ni Made Erlin. 2013. "Model Pembelajaran TGT Berbantuan Media Permainan Ular Tangga Berpengaruh terhadap Hasil Belajar Matematika Siswa Kelas IV SD Gugus VIII Sukawati".Jurnal.Universitas Pendidikan Ganesha

Permendikbud. 2014a. Peraturan Menteri Pendidikan dan Kebudayaan Republik Indonesia Nomor 57 Tahun 2014 Tentang Kurikulum 2013 Sekolah Dasar/Madrasah Ibtidaiyah. Jakarta: Kementerian Pendidikan dan Kebudayaan.

Permendikbud. 2014b. Peraturan Menteri Pendidikan dan Kebudayaan Republik Indonesia Nomor 103 Tahun 2014 Tentang Implementasi Kurikulum. Jakarta: Kementerian Pendidikan dan Kebudayaan.

Permendikbud. 2015. Peraturan Menteri Pendidikan dan Kebudayaan Republik Indonesia Nomor 53 Tahun 2015 Tentang Penilaian Hasil Belajar oleh Pendidik dan Satuan Pendidikan pada Pendidikan Dasar dan Pendidikan Menengah. Jakarta: Kementerian Pendidikan dan Kebudayaan.

Prastowo, Andi.2015. Menyusun Rencana Pelaksanaan Pembelajaran (RPP) Tematik Terpadu Implementasi Kurikulum 2013 untuk SD/MI.Jakarta: Prenadamedia Group. 
Rahayu, Sri. 2012.'Pembelajaran Kooperatif Metode Ular Tangga”. Tersedia pada http://sainssmp2ngawi.blogspot.co.id/2012/11/pembelajarankooperatifmetodeular.html_ (diakses tanggal 31 Januari 2017)

Runtukahu, Tombokan dan Selpius Kandou. 2014. Pembelajaran Matematika Dasar bagi Anak Berkesulitan Belajar. Yogyakarta: Ar-Ruzz-Media.

Russel, Deb. 2016. "Problem Solving in Mathematics". Tersedia pada http://math.about.com/od/1/a/ problemsolv.htm (diakses tanggal 31 Januari 2017)

Setyosari, Punaji. 2015. Metode Penelitian Pendidikan \& Pengembangan. Jakarta: Prenadamedia Group.

Shoimin, Aris. 2014. 68 Model Pembelajaran Inovatif dalam Kurikulum 2013. Yogyakarta: Ar-Ruzz Media.

Suarjana, I Made dan I Gusti Ngurah Japa. 2015. Buku Ajar Pendidikan Matematika III Berpendekatan PMRI \& Perubahan Konseptual. Singaraja: Universitas Pendidikan Ganesha.

Sudijono, Anas. 2012. Pengantar Evaluasi Pendidikan. Jakarta: Rajawali Press.

Sugiyono. 2014. Metode Penelitian Pendidikan Pendekatan Kuantitatif, Kualitatif, dan R\&D. Bandung: Alfabeta.

Susanto. 2015. Teori Belajar dan Pembelajaran di Sekolah Dasar. Jakarta: Prenadamedia Group.

Undang-Undang No. 20 Tahun 2003 tentang Sistem Pendidikan Nasional. Jakarta: Departemen Pendidikan Nasional. 